\title{
Endocrinological abnormalities and Takotsubo cardiomyopathy
}

\author{
Anu Anna George1, Kevin John John², Vijairam Selvaraj ${ }^{3}$, Ajay Kumar Mishra ${ }^{4}$ \\ ${ }^{1}$ Internal Medicine, Saint Vincent Hospital, Worcester, MA, USA; ${ }^{2}$ Internal Medicine, Believers Church Medical \\ College Hospital, Tiruvalla, Kerala, India; ${ }^{3}$ Internal Medicine, Warren Apert School of Brown University, Miriam \\ Hospital, Providence, RI, USA; ${ }^{4}$ Internal Medicine, Saint Vincent Hospital, Worcester, MA, USA
}

Dear Editor,

We read with much excitement in the article "Takotsubo syndrome and pheochromocytoma: an insidious combination" published by Maffé et al. in your esteemed journal. The authors have discussed in detail a 53-year-old gentleman who succumbed to Takotsubo syndrome in the background of a catecholaminergic storm secondary to ruptured pheochromocytoma following a fall [1]. We feel this topic is relevant and have the following addendum.

Takotsubo cardiomyopathy (TTC), also known as stress cardiomyopathy is traditionally thought to be treated by physical and emotional events. Over the past few years, there have been increasing reports of various endocrine abnormalities precipitating TTC. Table 1 shows the spectrum of endocrine abnormalities presenting with TTC as reported in Medline [2,3]. While pheochromocytoma and paraganglioma directly cause TTC secondary to catecholaminergic surge, the other endocrine abnormalities result in an augmentation of the catecholaminergic response through various mechanisms like i) exaggerated reactivity to stress during an autonomic surge in absence of cardioprotective peptides like estrogen, ii) potentiation of the effect of the normal level of catecholamine by thyroxine, iii) increased sensitivity to catecholamines in presence of steroid hormones [2].

Correspondence: Ajay Kumar Mishra, Resident in Internal Medicine, Saint Vincent Hospital, 123 Summer Street, Worcester, MA, USA. Tel. +1.508.363-5000. E-mail: Mishra@stvincenthospital.com

Conflict of interest: The authors declare that they have no competing interests, and all authors confirm accuracy.

Ethics approval: IRB clearance obtained.

Consent: Not required.

Contribution: AAG, AKM planned and formulated the study. AAG, KJJ collected and analyzed the data. AAG, AKM completed the manuscript. VS, AKM reviewed and approved the manuscript.

Received for publication: 21 March 2021.

Accepted for publication: 6 April 2021.

${ }^{\circ}$ Copyright: the Author(s), 2021

Licensee PAGEPress, Italy

Monaldi Archives for Chest Disease 2021; 91:1859

doi: 10.4081/monaldi.2021.1859

This article is distributed under the terms of the Creative Commons Attribution Noncommercial License (by-nc 4.0) which permits any noncommercial use, distribution, and reproduction in any medium, provided the original author(s) and source are credited.
We agree with the authors that patients with TTC usually have a good prognosis, with reported recovery in more than $95 \%$ of patients. However, in recent literature, various poor prognostic markers have been reported. Male gender, acute physiological,

Table 1. Showing the various reported endocrine causes precipitating Takotsubo cardiomyopathy.

\begin{tabular}{|c|c|}
\hline Thyroid disorder & $\begin{array}{l}\text { Thyrotoxicosis } \\
\text { - Endogenous (graves, Hashimoto) } \\
\text { - Exogenous (radio iodine, iatrogenic } \\
\text { thyroxine, porcine thyroxine) } \\
\text { - Thyroid storm } \\
\text { Hypothyroidism } \\
\text { Amiodarone induced hyperthyroidism } \\
\text { Post total thyroidectomy } \\
\text { Obstructive goiter }\end{array}$ \\
\hline Adrenal disorders & $\begin{array}{l}\text { Deficiency } \\
\text { - Primary adrenal insufficiency } \\
\text { - Secondary adrenal insufficiency } \\
\text { - Addisonian crisis } \\
\text { - Excess } \\
\text { - Adrenal adenocarcinoma } \\
\text { - Conns }\end{array}$ \\
\hline Catecholamine producing tumors & $\begin{array}{l}\text { Pheochromocytoma } \\
\text { Paraganglioma } \\
\text { MEN } 2 \text { A }\end{array}$ \\
\hline Diabetes mellitus & $\begin{array}{l}\text { DKA } \\
\text { HONCC } \\
\text { Hypoglycemia }\end{array}$ \\
\hline Pituitary & $\begin{array}{l}\text { Pituitary adenoma } \\
\text { Pituitary apoplexy } \\
\text { Empty sella } \\
\text { ACTH deficiency } \\
\text { Sheehan syndrome (all hormones) } \\
\text { Acromegaly } \\
\text { Cushing syndrome } \\
\text { TSH secreting adenoma } \\
\text { SIADH (Hyponatremia) }\end{array}$ \\
\hline Others & $\begin{array}{l}\text { APS } \\
\text { Menopause } \\
\text { Drugs: } \\
\text { - Levothyroxine } \\
\text { - Terlipressin } \\
\text { - Indapamide } \\
\text { - Water (Psychogenic polydipsia) } \\
\text { - Venlafaxine } \\
\text { - Triamterene }\end{array}$ \\
\hline
\end{tabular}

MEN2A, Multiple endocrine neoplasias; DKA, Diabetic ketoacidosis; HONC, Hyperosmolar nonketotic coma; ACTH, Adrenocorticotrophic hormone; TSH, Thyroid-stimulating hormone; SIADH, Syndrome of inappropriate ADH secretion; APS, Autoimmune polyglandular syndrome. 
psychological stress, severe left ventricular dysfunction (LVEF $<45 \%$ ), acute neurological pathology, and extremely high troponins ( $>10$ times from baseline) are associated with poor in-hospital outcomes, most of which were present in the reported patient [4]. Reported markers for long-term poor prognosis have been older age, reduced blood ventricular ejection fraction (LVEF $<45 \%$ ), presence of cardiogenic shock, presence of atrial fibrillation, or neurological pathologies [4,5].

Finally, nitro derivatives, which were used in the mentioned patient for reducing blood pressure can worsen pre-existing left ventricular outflow tract obstruction and hence requires extreme caution in patients with TTC.

\section{References}

1. Maffè S, Dellavesa P, Paffoni P, et al. Takotsubo syndrome and pheochromocytoma: an insidious combination. Monaldi Arch Chest Dis 2021. doi: 10.4081/monaldi.2021.1711. Epub ahead of print.

2. De Giorgi A, Fabbian F, Tiseo R, et al. Takotsubo cardiomyopathy and endocrine disorders: a mini-review of case reports. Am J Emerg Med 2014;32:1413-7.

3. Gupta S, Goyal P, Idrees S, et al. Association of endocrine conditions with takotsubo cardiomyopathy: A comprehensive review. J Am Heart Assoc 2018; 7:e009003.

4. Pelliccia F, Pasceri V, Patti G, et al. Long-term prognosis and outcome predictors in takotsubo syndrome: A systematic review and meta-regression study. JACC Heart Fail 2019;7:143-54.

5. Sahu KK, Mishra AK, Lal A. Newer insights into Takotsubo cardiomyopathy. Am J Med 2020;133:e318. 